\title{
Attraction of Schistosoma mansoni Sambon, 1907 miracidia to Biomphalaria glabrata (Say, 1818) in the presence of Angiostrongylus costaricensis Morera and Céspedes, 1971 infection
}

\author{
Guerino, LR., Linhares, AX., Magalhães, LA. and Zanotti-Magalhães, EM.* \\ Departamento de Parasitologia, Instituto de Biologia, \\ Universidade de Campinas - UNICAMP, \\ Cidade Universitária, Barão Geraldo, CP 6109, CEP 13083-970, Campinas, SP, Brazil \\ *e-mail: emzm@unicamp.br
}

Received July 3, 2008 - Accepted November 18, 2008 - Distributed November 30, 2009

\begin{abstract}
The attraction exerted by Biomphalaria glabrata infected with Angiostrongylus costaricensis on Schistosoma mansoni miracidia of the $\mathrm{BH}$ strain was tested, using a glass apparatus composed by two circular chambers connected to a channel. One mollusk or a sample of a snail conditioning water (SCW) was placed in one of the chambers, randomly selected, and the remaining of the apparatus was filled with chlorine-free water. Ten miracidia were placed in the centre of the channel and their behaviour was observed for 15 minutes. Ten replicates were made for each treatment (snail or SCW), using different specimens of mollusks or different samples of SCW. Mollusks infected with A. costaricensis attracted significantly less $S$. mansoni miracidia than non-infected B. glabrata. In addition, miracidia were also significantly more attracted to SCW from mollusks infected with A. costaricensis.
\end{abstract}

Keywords: Angiostrongylus costaricensis, Schistosoma mansoni, Biomphalaria glabrata, miracidia.

\section{Atração de miracídios de Schistosoma mansoni Sambon, 1907 por Biomphalaria glabrata (Say, 1818) infectada por Angiostrongylus costaricensis Morera and Céspedes, 1971}

\begin{abstract}
Resumo
Utilizando-se um artefato de vidro composto por duas câmaras unidas por um canal, testamos a atração miraxonal exercida por Biomphalaria glabrata infectada por Angiostrongylus costaricensis sobre miracídios de Schistosoma mansoni da linhagem BH. Um molusco ou uma amostra de sua água de condicionamento (SCW) foi colocado aleatoriamente em uma das câmaras, sendo o restante do artefato preenchido com água declorada. Dez miracídios foram colocados no centro do canal e seu comportamento foi observado por 15 minutos. Foram feitas dez replicações de cada experimento utilizando-se espécimes de moluscos ou de amostras de SCW diferentes. Moluscos infectados com A. costaricensis atraíram significativamente menos miracídios de $S$. mansoni que B. glabrata não infectada. Além disso, miracídios foram significativamente mais atraídos pela SCW de moluscos infectados com A. costaricensis.
\end{abstract}

Palavras-chave: Angiostrongylus costaricensis, Schistosoma mansoni, Biomphalaria glabrata, miracídio.

\section{Introduction}

Human infection by the nematode Angiostrongylus costaricensis (Morera and Céspedes, 1971), is known as abdominal angiostrongiliasis. Human infection is considered accidental, and wild rodents serve as definitive hosts. This disease was first identified in Central America (Tesh et al., 1973), from Sigmodon hispidus Say and Ord, 1835 (Rodentia: Cricethidae), and later from Orizomys nigripes Olfers, 1818 and Orizomys ratticeps Hensel, 1873 in southern Brazil (Graeff-Teixeira et al., 1990). The usual intermediate hosts are terrestrial mollusks of the family Veronicellidae (slugs), specially species of the genera Sarasinula (Laitano et al., 2001), and Phyllocaulis (Graeff-Teixeira et al., 1989a), as well as the species Limax maximus Linnaeus, 1758, L. flavus Linnaeus, 1758 and also Bradybaena similaris Férrussac, 1821, Belocaulus angustipes Heyneman, 1885 (Graeff-Teixeira et al., 1993), Helix aspersa Müller, 1774 (Thiengo et al., 1993) and Deroceras laeve (Müller, 1774) (Maurer et al., 2002). In the laboratory, several species of mollusks such as Biomphalaria glabrata, B. tenagophila (d'Orbigny, 1835), B. straminea (Dunker, 1848), Megalobulimus sp. and Achatina fulica Bodwdich, 1822 were found to be 
susceptible to A. costaricensis (Graeff-Teixeira et al., 1989b; Monge et al., 1978; Lima et al., 1992; Carvalho et al., 2003).

The evidence of attraction exerted by vector mollusks to Schistosoma mansoni miracidia was suggested by Kloetzel (1958) when observing the behaviour of the trematode in the presence of B. glabrata. Apparently, the attraction exerted by the intermediate hosts to the miracidia is caused by substances released in the water by the mollusk, which are denominated as SCW (snail-conditioned water, Chernin, 1972). Analyses of the hemolymph and the SCW of B. glabrata and B. tenagophila (Brasio et al., 1985b) show some cations and amino acids ( $\mathrm{Na}, \mathrm{K}, \mathrm{Mg}, \mathrm{Ca}, \mathrm{NH}$, alanine, glycine, valine, treonine, serine, leucine, proline, metionine, acid aspartic, fenilalanine, glutamic acid, lisine, tyrosine, arginine) as responsible to the miracidia attraction. Paraense and Corrêa (1963), when studying the BH and SJ strains of $S$. mansoni, described that the intensity of miracidia attraction is dependent on the trematode strain and of the planorbid species. Brasio et al. (1985a) verified that, in addition to SCW, the mucus and the feces of the mollusks also exerted strong attraction to the miracidia.

Machado et al. (1988) and Balan et al. (1993) showed that the infection by $S$. mansoni did not develop in $B$. tenagophila previously infected by furcicercariae either with or without ocellli. The presence of primary or secondary sporocysts of $S$. mansoni in B. glabrata (Seta et al., 1993; Magalhães et al., 1997) induced the loss of the attractiveness to miracidia, which results in an advantage for the trematode, for it is more attracted to non-parasited mollusks.

In this work we verified the attractiveness of B. glabrata infected with $A$. costaricensis to $S$. mansoni miracidia.

\section{Material and Methods}

Melanic specimens of $B$. glabrata from Belo Horizonte (MG, Brazil) and the sympatric S. mansoni strain maintained in mice Swiss, SPF, were used. The Crisciumal (RS, Brazil) strain of A. costaricensis was used, and maintained in B. glabrata and Sigmodon hispidus (cotton-rat). Larvae (L1) of A. costaricensis were obtained from the feces of $S$. hispidus, using the method of Rugai et al. (1954). For infection of B. glabrata, 120 larvae (L1) of $A$. costaricensis were used. The exposure period of the mollusks to the larvae was 12 hours and the infected mollusks were used in the experiments after 20 hours. Samples of the snail-conditioning wa- ter (SCW) prepared according to Chernin (1972) were also tested. The samples of SCW were prepared with non-infected mollusks and with mollusks infected with A. costaricensis.

A glass apparatus composed of two circular chambers (A and B), $30 \mathrm{~mm}$ in diameter and $20 \mathrm{~mm}$ in depth, attached to a $40 \mathrm{~mm} \times 11 \mathrm{~mm}$ channel (C), as described by Brasio et al. (1985a) were used in the experiments. Four groups were used in the experiments: Group I - 10 specimens of non-infected B. glabrata; Group II -10 specimens of B. glabrata infected with A. costaricensis; Group III -10 samples of SCW of non-infected B. glabrata; Group IV - 10 samples of SCW of B. glabrata infected with A. costaricensis. The glass apparatus have been filled with chlorine-free water and the mollusks or the samples of SCW were randomly placed in one of the chambers (A). Ten S. mansoni miracidia of the $\mathrm{BH}$ strain were deposited with a pipette in the centre of channel " $\mathrm{C}$ ". The behaviour of the miracidia was then observed for fifteen minutes using a stereoscopic microscope $(\times 0.5)$ and with abundant and homogenously distributed illumination. After fifteen minutes, the number of miracidia which migrated to each chamber was recorded. The experiments were repeated ten times and in each replication different specimens of mollusks or samples of SCW were tested. After each observation, the apparatus was carefully washed to remove any mucus tracks and feces that could interfere with the observations (Brasio et al., 1985a).

The attractiveness to the miracidia was statistically analysed using the PROC GLM (General Linear Model), procedure of the SAS ${ }^{\circledR}$ software (Statistical Analysis System, SAS Institute, 2006). Differences among the means were tested by the Duncan multiple comparisons test.

\section{Results}

The results are presented in Table 1. There was a significant difference in the attractiveness exerted by the infected mollusks to the miracidia when compared to the mollusks non-infected with $A$. costaricensis $(\mathrm{F}=4.47$; $\mathrm{P}=0.0487$ ). The miracidia attraction exerted by SCW to the infected mollusks and by the SCW from non-infected mollusks were not significantly different $(\mathrm{F}=1.17$; $\mathrm{P}=0.2945$ ) (Table 2). The Duncan test did not detect any significant differences in the attractiveness exerted to the miracidia by the SCW from infected and not-infected snails $(\mathrm{F}=0.13 ; \mathrm{P}=0.7183$ ) (Table 3$)$. In addition, the SCW from infected snails attracted significantly more miracidia than the infected snails $(\mathrm{F}=7.71 ; \mathrm{P}=0.0124)$ (Table 4).

Table 1. Mean number of miracidia of S. mansoni attracted for B. glabrata not infected (NI) or infected (I) by A. costaricensis.

\begin{tabular}{cccc}
\hline Duncan test* & Miracidia $($ Mean $\pm \mathbf{s d})$ & Number of mollusks & Treatment \\
\hline A & $8.6 \pm 1.26$ & 10 & NI \\
B & $7.1 \pm 1.85$ & 10 & I \\
\hline
\end{tabular}

*Mean values with the same letter are not significantly different (overall error rate $(\alpha)=0.05$ ). 
Table 2. Mean number of miracidia of S. mansoni attracted for SCW of B. glabrata not infected (SCWNI) or infected (SCWI) by A. costaricensis.

\begin{tabular}{cccc}
\hline Duncan test* & Miracidia $($ Mean $\pm \mathbf{s d})$ & Number of mollusks & Treatment \\
\hline A & $8.9 \pm 0.87$ & 10 & SCWI \\
A & $8.4 \pm 1.17$ & 10 & SCWNI \\
\hline
\end{tabular}

*Mean values with the same letter are not significantly different (overall error rate $(\alpha)=0.05$ ).

Table 3. Mean number of miracidia of S. mansoni attracted for B. glabrata not infected (NI) or for its SCW (SCWNI).

\begin{tabular}{cccl}
\hline Duncan test* & $\begin{array}{c}\text { Miracidia } \\
(\text { Mean } \pm \mathbf{s d})\end{array}$ & $\begin{array}{c}\text { Number of mollusks } \\
\text { or SCW samples }\end{array}$ & \multicolumn{1}{c}{ Treatment } \\
\hline A & $8.6 \pm 1.26$ & 10 & NI \\
A & $8.4 \pm 1.17$ & 10 & SCWNI \\
\hline
\end{tabular}

*Mean values with the same letter are not significantly different (overall error rate $(\alpha)=0.05$ ).

Table 4. Mean number of miracidia of S. mansoni attracted for B. glabrata infected (I) by A. costaricensis or for its SCW (SCWI).

\begin{tabular}{cccc}
\hline Duncan test* & Miracidia (Mean \pm sd) & $\begin{array}{c}\text { Number of mollusks or } \\
\text { samples SCW }\end{array}$ & Treatment \\
\hline A & $8.9 \pm 0.87$ & 10 & SCWI \\
B & $7.1 \pm 1.85$ & 10 & I \\
\hline
\end{tabular}

*Mean values with the same letter are not significantly different (overall error rate $(\alpha)=0.05$ ).

\section{Discussion}

The success of parasitism can be attributed partly to the parasite's finding of the host, that can be nearby or far. Therefore, the existence of substances that attract the parasites in the vicinity of the host constitutes an important strategy for the success of parasitism. Chernin (1972) and later Brasio et al. (1985b), evidenced amino acids and cations present in the conditioning water of the mollusks and in the hemolymph that attracted S. mansoni miracidia.

In our experiment, B. glabrata without infection with A. costaricensis, (group I) attracted $86 \%$ of $S$. mansoni miracidia, and B. glabrata infected with A. costaricensis attracted $71 \%$. Although we have verified significant reduction in the attraction ability by the mollusk infected with $A$. costaricensis, nevertheless, we noted that $B$. glabrata infected with this nematode continues to exercise strong attraction to miracidia. Using B. tenagophila previously infected with S. mansoni, Seta (1996) obtained $70 \%$ of attraction with miracidia of the SJ strain, results that are similar to ours. In contrast, when using B. glabrata previously infected with S. mansoni, the author obtained only $17 \%$ of miracidia attraction. B. glabrata infected with S. mansoni, containing primary sporocysts (Seta et al., 1993) or secondary sporocysts (Magalhães et al., 1997) lost the ability to attract miracidia, the same occurring with SCW.

When we submitted $\mathrm{BH}$ miracidia to the SCW of non-infected B. glabrata, (group III), we obtained $84 \%$ of miracidia attraction. Seta (1996) obtained $100 \%$ of miraxonal attraction when exposing $\mathrm{BH}$ miracidia to SCW of non-infected B. glabrata. Studies done by Machado et al. (1988) in concomitant infections by different species of trematode (Digenea) in B. tenagophila showed that the development of natural infection of mollusks was frequently monospecific. Mollusks naturally infected by cercariae of species of Echinostomatidae and by aculeate cercariae of Distomata (Digenea) presented partial resistance to the development of experimental superinfection with $S$. mansoni, with resistance rates of 73 and $87 \%$, respectively. According to Balan et al. (1993), samples of B. tenagophila naturally parasitised by trematodes and experimentally superinfected with S. mansoni, showed resistance to the development of sporocysts of $S$. mansoni. However, Yousif and Lämmler (1977) verified that previous infection of B. glabrata with A. cantonensis did not inhibit nor delay the subsequent infection of the mollusks with $S$. mansoni.

Biochemical alterations in the mollusks infected with $S$. mansoni were verified by several authors (Target, 1962; Gilbertson et al., 1967; Michelson and Dubois, 1973; Brasio et al., 1985b; Seta, 1996). Studies done by Stewart et al. (1985) showed an elevation in the levels of glucose and enzymes in the hemolymph of $B$. glabrata infected with $A$. costaricensis, as a consequence of the alterations in the parasitised tissue, characterised by the intense haemocytic reaction around the larvae (Zanotti-Magalhães et al., 2007). Brasio et al. (1985b) and Seta (1996) reported that the mollusk SCW exerted greater attraction than that exerted by the mollusk alone. Alterations in the chemical constitution of the conditioning water (SCW) from mollusks infected with 
A. costaricensis that were kept in this SCW water for 24 hours, could explain the greater attraction exerted by the SCW water compared with the attractions exerted by the mollusk alone, when it was kept for only 15 minutes in the chamber of the miraxonal attraction apparatus. Seta (1996) observed that B. glabrata (or its SCW) infected with $S$. mansoni repelled miracidia of the trematode, whereas B. tenagophila (or its SCW) infected with $S$. mansoni exerted a more intense attraction to the miracidia of this trematode than the non-infected mollusks. An alteration in the composition and in the concentration of the aminoacids was found.

We concluded that $B$. glabrata infected by A. costaricensis showed a low intensity attraction to $S$. mansoni miracidia of the $\mathrm{BH}$ strain. The conditioning water of B. glabrata infected by A. costaricensis attracted more $\mathrm{BH}$ miracidia than the mollusks infected with the nematode.

\section{References}

BALAN, DSL., MAGALHÃES, LA. and PIEDRABUENA, AE., 1993. Immunological and parasitological aspects of Biomphalaria tenagophila infected by Schistosoma mansoni and other Digenea. Revista de Saúde Pública, vol. 27, no. 6, p. 421-429.

BRASIO, BC., MAGALHÃES, LA., MILLER, J. and CARVALHO, JF. 1985a. Atração de miracídios de Schistosoma mansoni por hospedeiros invertebrados: comportamento de miracídios frente a girinos de Hyla fuscovaria. Revista de Saúde Pública, vol. 19, no. 1, p. 18-27.

BRASIO, BC., MAGALHÃES, LA., MILLER, J. and CARVALHO, JF. 1985b. Verificação da resposta de miracídios de Schistosoma mansoni a substâncias provenientes de moluscos planorbídeos. Pesquisa de substâncias quimiotáxicas. Revista de Saúde Pública, vol. 19, no. 2, p. 154-170.

CARVALHO, OS., TELES, HMS., MOTA, EM., MENDONÇA, CLGF. and LENZI, HL., 2003. Potentiality of Achatina fulica Bodwdich, 1822 (Mollusca: Gastropoda) as intermediate host of the Angiostrongylus costaricensis Morera e Céspedes 1971. Revista da Sociedade Brasileira de Medicina Tropical, vol. 36, no. 6, p. 1-6.

CHERNIN, E. 1972. Penetrative activity of Schistosoma mansoni miracidia stimulated by exposure to snail conditioned water. The Journal of Parasitology., vol. 58, no. 2, p. 209-212.

GILBERTSON, DE., ETGES, FJ. and OGLE, JD., 1967. Free amino acids of Australorbis glabratus hemolymph: comparison of four geographic strains and effect of infection by Schistosoma mansoni. The Journal of Parasitology, vol. 53, no. 3, p. 565-568.

GRAEFF-TEIXEIRA, C., THOMÉ, JW., PINTO, SCC., CAMILO-COURA, L. and LENZI, HL., 1989a. Phyllocaulis variegatus: an intermediate host of Angiostrongylus costaricensis in South Brazil. Memórias do Instituto Oswaldo Cruz, vol. 84, no. 1, p. 65-68.

GRAEFF-TEIXEIRA, C., CAMILO-COURA, L. and LENZI, HL., 1989b. Suscetibilidade de Megalobulimus $s p$. à infecção por larvas de Angiostrongylus costaricensis. In Anais do 11 Congresso Brasileiro de Parasitologia. Rio de Janeiro. p. 151.
GRAEFF-TEIXEIRA, C., ÁVILA-PIRES, FD., MACHADO, RCC., CAMILO-COURA, L. and LENZI, HL., 1990. Identificação de roedores silvestres como hospedeiros do Angiostrongylus costaricensis no sul do Brasil. Revista do Instituto de Medicina Tropical de São Paulo, vol. 32, no. 3, p. $147-150$.

GRAEFF-TEIXEIRA, C., THIENGO, SC., THOMÉ, JW., MEDEIROS, AB., CAMILO-COURA, L. and AGOSTINI, AA., 1993. On the diversity of mollusc intermediate hosts of Angiostrongylus costaricensis Morera e Céspedes, 1971 in southern Brazil. Memórias do Instituto Oswaldo Cruz, vol. 88, no. 3 , p. 487-489.

KLOETZEL, K., 1958. Observações sobre o tropismo do miracídio do Schistosoma mansoni pelo molusco Australorbis glabratus. Revista Brasileira de Biologia $=$ Brazilian Journal of Biology, vol. 18, no. 2, p. 223-232.

LAITANO, AC., GENRO, JP., FONTOURA, R., BRANCO, SSL., MAURER, RL., GRAEFF-TEIXEIRA, C., MILANEZ, JM., CHIARADIA, LA. and THOMÉ, JW., 2001. Report on the ocurrence of Angiostrongylus costaricensis in southern Brazil, in new intermediate host from the genus Sarasinula (Veronicellidae, Gastropoda). Revista da Sociedade Brasileira de Medicina Tropical, vol. 34, no. 1, p. 95-97.

LIMA, LC., MASSARA, CL., SOUZA, CP., VIDIGAL, TD., LENZI, HL. and CARVALHO, OS., 1992. Suscetibilidade de planorbídeos da região metropolitana de Belo Horizonte, MG (Brasil) ao Angiostrongylus costaricensis (Nematoda Angiostrongylidae). Revista do Instituto de Medicina Tropical de São Paulo, vol. 34, no. 5, p. 399-402.

MACHADO, SMP., MAGALHÃES, LA., ARTIGAS, PT., CORDEIRO, NS. and CARVALHO, JF., 1988. Verificação de antagonismo entre larvas de Schistosoma mansoni e larvas de outros Digenea em Biomphalaria tenagophila molusco planorbídeo de criadouro natural situado na região de Campinas, SP, Brasil. Revista do Instituto de Medicina Tropical de São Paulo, vol. 22, no. 6, p. 484-488.

MAGALHÃES, LA., ZANOTTI-MAGALHÃES, EM. and CARVALHO, JF., 1997. Observations on the miraxonal attraction exercised by sexually immature or adult Biomphalaria glabrata infected or not by Schistosoma mansoni. Revista do Instituto de Medicina Tropical de São Paulo, vol. 31, no. 2, p. 1421-124.

MAURER, RL., GRAEFF-TEIXEIRA, C., THOMÉ, JW., CHIARADIA, LA., SUGAYA, H. and YOSHIMURA, K., 2002. Natural infection of Deroceras laeve (Mollusca: Gastropoda) with metastrongylid larvae in a transmission focus of abdominal angiostrongyliasis. Revista do Instituto de Medicina Tropica de São Paulo, vol. 44, no. 1, p. 53-54.

MICHELSON, EH. and DUBOIS, L., 1973. Increase alkaline phosphatase in the tissues and hemolymph of the snail Biomphalaria glabrata infected with Schistosoma mansoni. Comparative Biochemistry and Physiology, vol. 44, no. 3, p. $763-767$.

MONGE, EA., ARROYO, R. and SOLANO, E., 1978. A new definitive host of Angiostrongylus costaricensis (Morera and Céspedes 1971). The Journal of Parasitology, vol. 64, no. 1, p. 34.

MORERA, P. and CÉSPEDES, R., 1971. Angiostrongylus costaricensis n. sp. (Nematoda: Metastrongyloidea), a new lungworm occurring in man in Costa Rica. Revista de Biologia Tropical, vol. 18, no. 1, p. 173-185. 
PARAENSE, WL. and CORRÊA, LR., 1963. Sobre a ocorrência de duas raças biológicas do Schistosoma mansoni no Brasil. Ciência e Cultura, vol. 15, no. 3, p. 245-246.

RUGAI, E., MATOS, T. and BRIZOLA, AP., 1954. Nova técnica para isolar larvas e nematóides das fezes: modificação da técnica de Baermann. Revista do Instituto Adolfo Lutz, vol. 14 , no. 1 , p. $5-8$.

SAS STAT User's Manual. Available from:<http://support.sas. com/onlinedoc/913/docMainpage.jsp>.

SETA, L., MAGALHÃES, LA., ZANOTTI-MAGALHÃES, EM., OLIVEIRA-FILHO, B., MARANGONI, S., CARVALHO, JF. and REIS, ER., 1993. Estudo da atração miraxonal em Biomphalaria glabrata e Biomphalaria tenagophila livres de infecção ou infectados por Schistosoma mansoni. Revista Brasileira de Parasitologia Veterinária, vol. 2, no. 2 (suplemento 1), p. 51.

SETA, L., 1996. Estudo da atração miraxonal e da composição bioquímica da hemolinfa, da água de condicionamento e da glândula do albúmen de Biomphalaria glabrata e Biomphalaria tenagophila infectadas por Schistosoma mansoni. Campinas: Universidade Estadual de Campinas. [Tese de Doutorado].

STEWART, GL., UBELAKER, JE. and CURTIS, D., 1985. Pathophysiology alterations in Biomphalaria glabrata infected with Angiostrongylus costaricensis. Journal of Invertebrate Pathology, vol. 45, no. 2, p. 152-157.
TARGET, GAT., 1962. A study of the amino acids present in Lymnaea stagnalis, Planorbarius corneus and Australorbis glabratus before and after infection with Schistosoma mansoni. Annals of Tropical Medicine and Parasitology, vol. 56, no. 2, p. $210-215$.

TESH, RB., ACKERMAN, LJ., DIETZ, WH. and WILLIAMS, JA., 1973. Angiostrongylus costaricensis in Panama. Prevalence and pathologic findings in wild rodents infected with the parasite. The American Journal of Tropical Medicine and Hygiene, vol. 22, no. 3, p. 348-356.

THIENGO, SC., AMATO, SB., AVENTINO, A. and ARAÚJO, JLB., 1993. Estudo sobre os hospedeiros intermediários do Angiostrongylus costaricensis Morera e Céspedes, 1971. Revista Brasileira de Parasitologia Veterinária, vol. 2, no. 2 (suplemento 1), p. 64.

YOUSIF, F. and LÄMMLER, G., 1977. Experimental double infection of Biomphalaria glabrata snails with Angiostrongylus cantonensis and Schistosoma mansoni. Zeitschrift fur Parasitenkunde, vol. 54, no. 3, p. 269-274.

ZANOTTI-MAGALHÃES, EM., BANEVICIUS, NMS., BRUNO, TIB., MAGALHÃES, LA. and LINHARES, AX., 2007. Planorbídeos como hospedeiros de Angiostrongylus costaricencis Morera e Cespedes. In SANTOS, SB., PIMENTA, AD., THIENGO, SC., FERNANDEZ, MA., ABSALÃO, RS. (Orgs.). Tópicos em Malacologia. Anais do 18 Encontro Brasileiro de Malacologia. Rio de Janeiro: SBMa. 365 p. 